\title{
TRACING PAST CIRCULATION CHANGES IN THE WESTERN SOUTH ATLANTIC BASED ON PLANKTONIC FORAMINIFERA
}

\author{
FELIPE A. L. TOLEDO, KAREN B. COSTA, MARÍA A. G. PIVEL \& EDMO J. D. CAMPOS \\ Departamento de Oceanografia Física, Química e Geológica, IO, Praça do Oceanográfico 191, USP, \\ 05508-900, SP, Brazil.felipe.toledo@io.usp.br,karen.costa@io.usp.br, mariale33@gmail.com,edmo@io.usp.br
}

\begin{abstract}
In this study, we traced past oceanographic changes in the southeastern Brazilian Continental Margin based on the ratio between two planktonic foraminifera species (Globigerina bulloides and Globigerinoides ruber), along a core located close to the transition between the tropical and subtropical biogeographic provinces. Each species is representative of a biogeographic province and has excluding ecological preferences. According to our interpretation, periods of low $G$. bulloides/G. ruber values would characterize a stronger influence of the warm, oligotrophic tropical water and, conversely, periods of high G. bulloides/G. ruber values correspond to a stronger influence of colder and nutrient-richer waters. Changes in the relative influence of the different water masses are strongly dependent on the regional wind field which affects the upper-level circulation mostly by the latitudinal displacement of the bifurcation of the South Equatorial Current which, in turn, has strong impacts on the Brazil Current's strength and on the intensity of the upwelling regime in the study area. The analysis of the last $30 \mathrm{kyr}$ record, suggests that productivity was highly increased both around the Last Glacial Maximum and the Younger Dryas event. In between these events, the record suggests that productivity was severely decreased during deglaciation. Also, our record suggests a gradual decrease in productivity from $11 \mathrm{kyr}$ BP through the Holocene which can be explained by a progressively stronger Brazil Current resulting from a southward displacement of the Intertropical Convergence Zone. Our results are consistent with other studies providing estimates of changes in trade wind strength and in the extent of the climatic belts through time.
\end{abstract}

Key words: Planktonic foraminifera, paleoceanography, productivity, South Atlantic.

RESUMO - No presente estudo, analisamos mudanças paleoceanográficas na Margem Continental Brasileira a partir da análise da razão entre duas espécies de foraminíferos planctônicos (Globigerina bulloides e Globigerinoides ruber), ao longo de um testemunho localizado próximo à transição entre as províncias biogeográficas Tropical e Subtropical. Cada espécie é representativa de uma província biogeográfica e possui preferências ecológicas próprias. De acordo com a nossa interpretação, períodos de baixa razão G. bulloides/G. ruber caracterizariam uma maior influencia de águas quentes e oligotróficas enquanto, períodos de alta razão G. bulloides/G. ruber corresponderiam a uma maior influência de águas frias e ricas em nutrientes. Variações na influência relativa das diferentes massas d'água são fortemente dependentes do campo de ventos regional o que afeta a circulação superficial, principalmente pelo deslocamento latitudinal da bifurcação da Corrente Sul Equatorial. Isto determina a intensidade da Corrente do Brasil e do regime de ressurgência na área de estudo. A análise do registro dos últimos 30 mil anos sugere que a produtividade aumentou significativamente ao redor do Último Máximo Glacial e do evento Younger Dryas. Entre ambos eventos, o nosso registro sugere que a produtividade diminui severamente durante a deglaciação. O registro também sugere uma diminuição gradual da produtividade desde 11 mil anos atrás ao longo do Holoceno, o que pode ser explicado por uma Corrente do Brasil progressivamente mais intensa, resultante de um deslocamento para o sul da Zona de Convergência Intertropical. Os resultados são consistentes com outros estudos que proporcionam estimativas de mudanças na intensidade dos ventos alísios e na extensão dos cinturões climáticos ao longo do tempo.

Palavras-chave: Foraminíferos planctônicos, paleoceanografia, produtividade, Atlântico Sul.

\section{INTRODUCTION}

The distribution and abundance of planktonic foraminifera is governed by the interaction of multiple biotic and abiotic factors such as food supply, predation, productivity, algal symbionts, reproductive behaviour, nutrients, light, temperature, salinity, turbidity, circulation, etc. (e.g. Bé \& Hutson, 1977; Hemleben et al., 1989). Although temperature plays the dominant role on a global scale, within a more restricted geographical scale, foraminiferal distribution is strongly dependent on food availability (Kemle-von Mücke \& Hemleben, 1999). This is particularly true at low latitudes where the vertical structure of the water column seems to be crucial in determining food availability (e.g. Ravelo et al., 1990; Ravelo \& Andreasen, 1999).

Nevertheless, since large scale species distribution is mostly dependent on water mass temperature (Morey et al., 2005) and ocean circulation, it is largely related to climatic 


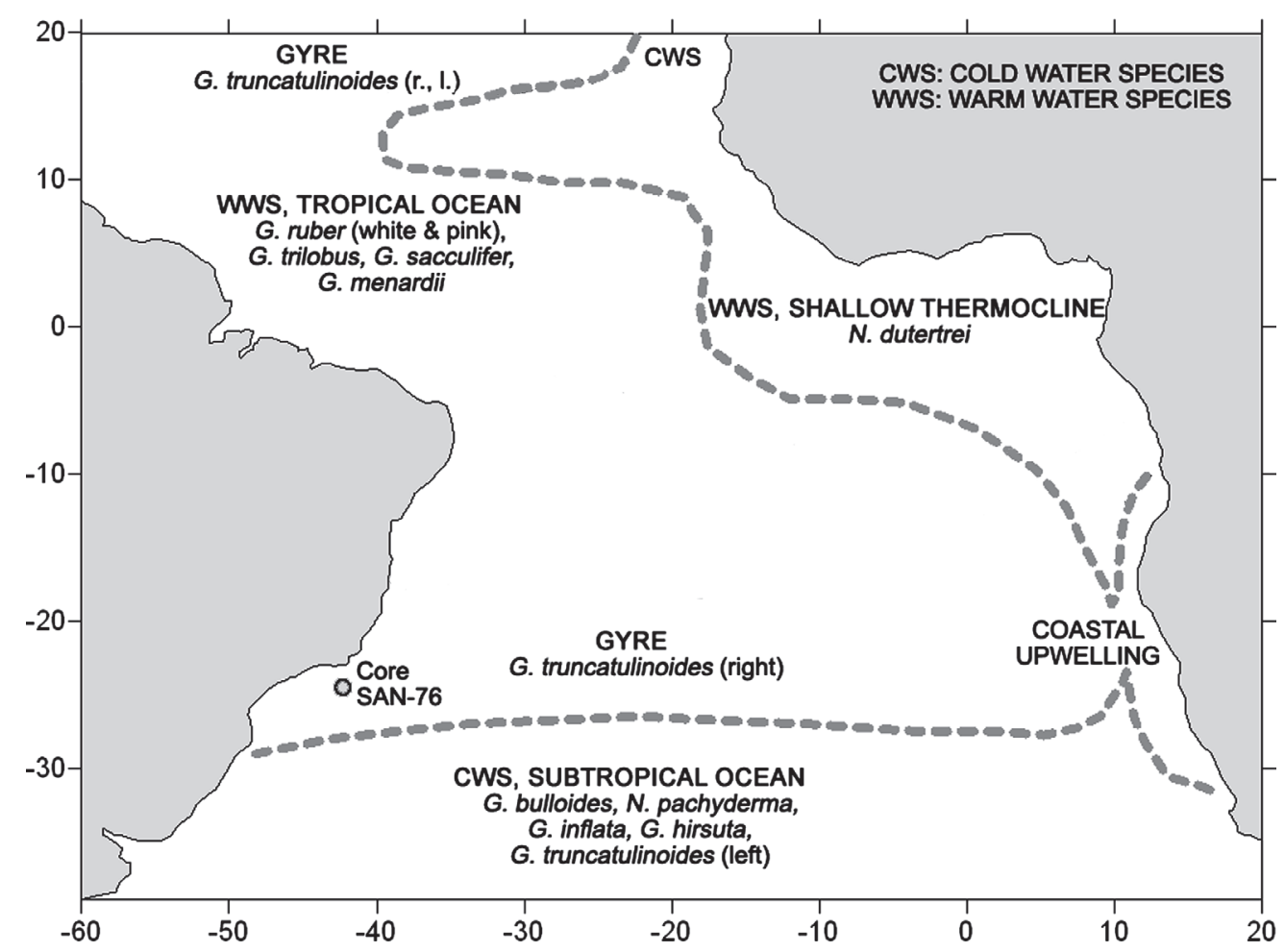

Figure 1. Location of Core SAN-76 relative to the generalized planktonic foraminiferal biogeographic zones in the South Atlantic according to Kemle-von Mücke and Hemleben, 1999.

belts. As a result, nine major biogeographic zones can be distinguished, distributed in a symmetrical bipolar pattern, namely the Polar (Arctic and Antarctic), Subpolar (Subarctic and Antarctic), Transitional (Temperate) and Subtropical (in both hemispheres), and Tropical faunal provinces (Boltovskoy \& Wright, 1976; Bé, 1977; Arnold \& Parker, 1999). Figure 1 shows the generalized planktonic foraminiferal biogeographic zones in the South Atlantic according to Kemle-von Mücke \& Hemleben (1999).

The biogeographic zones depicted in Figure 1 represent modern conditions. Given the intense global climate changes that have occurred since the last glaciation, it is reasonable to assume that the surface circulation and the geographical extension and configuration of these biogeographic zones very likely changed through time. In order to investigate this hypothesis, we decided to analyze the past changes in the ratio of two species indicative of respectively the tropical and subtropical assemblages in a core located in the Brazilian Continental Margin close to the transition between both biogeographic provinces (Figure 1). The species chosen were Globigerinoides ruber (white) and Globigerina bulloides.

The warm water species $G$. ruber dominates the tropical assemblage. Its geographic distribution is clearly related to water temperature (Figures 2, 3) (Hilbrecht, 1996). G. bulloides can be found in a wide range of thermal environments (Figure 2) from subpolar to tropical ocean waters, although it is generally more abundant in cool subtropical/transitional waters (Figure 3 ). Its abundance increases considerably during periods of high phytoplankton productivity which may result from spring bloom conditions or upwelling (Sautter $\&$ Thunell, 1991). The use of G. bulloides and G. ruber has been suggested in previous studies to infer past changes in general thermal gradients (Tolderlund \& Bé, 1971) and productivity (Conan et al., 2002). In this paper, we demonstrate the use of G. ruber (white)/G. bulloides ratio as a proxy for oceanographic changes related to circulation and upwelling that occurred in the western South Atlantic in the last $30 \mathrm{kyr}$.

\section{PRESENT OCEANOGRAPHIC SETTING}

The wind-driven circulation in the South Atlantic is dominated by an anticyclonic gyre bordered on the north by the South Equatorial Current (SEC). The southern boundary is the Subtropical Convergence Zone (STCZ), a region of vanishing wind stress curl, with zonal flow formed by the eastward extension of the Brazil Current (BC), the South Atlantic western boundary current flowing poleward. The $\mathrm{BC}$, originated by the southern branch of the SEC bifurcation, carries to the south warm and saline tropical aters (TW) in the upper 200 meters. Below that depth, the BC is formed mainly by the cooler, fresher and nutrient-richer South Atlantic Central Water (SACW) (Figure 4).

Near $22^{\circ} \mathrm{S}$ (Cabo Frio), the orientation of the South American coastline changes abruptly from a predominantly north-south orientation to practically east-west. This flow divergence due to the change in the coastline orientation, associated with the northeasterly wind and the strong $\mathrm{BC}$ meandering (Campos et al., 1995) results in a relatively strong upwelling regime, which pumps large amounts of the SACW to the upper slope and continental shelf (Campos et al., 2000). Regional upwelling brings cool, nutrient-rich waters into the photic zone, affecting local productivity. 
As shown by Stramma (1989), the South Atlantic subtropical gyre shows a strong baroclinicity in its northwestern sector, with the SEC bifurcation tilted to the south with depth. Near the surface, it is usually observed at approximately $5^{\circ} \mathrm{S}$. At $500 \mathrm{~m}$ depth, the eastward flow bifurcates at around $20^{\circ} \mathrm{S}$. Since the SEC is part of the winddriven subtropical gyre, its bifurcation is dependent on the wind regime over the basin. Seasonal changes in the wind field and the migration of the Intertropical Convergence Zone (ITCZ) are responsible for changes in the upper-level circulation. During the austral winter, when the ITCZ is at its northernmost position and the SE trade winds extend well into the northern hemisphere, the flow of the North Brazil Current (NBC) is strengthened, reaching a maximum during austral spring which is counterbalanced by a weakened BC (Johns et al., 1998; Kim \& Schneider, 2003). Conversely, during the austral summer, when the ITCZ is at its southernmost position and the NE trade winds are strongest, the NBC is weakened reaching a minimum during austral fall, and the $\mathrm{BC}$ is strengthened. The strengthening of the $\mathrm{BC}$ results in a southward displacement of the Brazil-Malvinas Confluence (Matano et al., 1993; Goni \& Wainer, 2001).

\section{MATERIAL AND METHODS}

Core SAN-76 was recovered from the Brazilian Continental Margin in the southwestern Atlantic $\left(24^{\circ} 25^{\prime} 48^{\prime \prime} \mathrm{S}\right.$, $42^{\circ} 16^{\prime} 48^{\prime \prime} \mathrm{W}$ ) at $1682 \mathrm{~m}$ water depth. The core was sampled at intervals of 5 to $10 \mathrm{~cm}$. This study covers the last $30 \mathrm{kyr}$, corresponding to 36 samples. Initially, raw sediment samples were shaken in distilled water and sieved over a $63 \mathrm{~mm}$ mesh. The large fraction was subsequently sieved again and foraminifera counts were made on the $>150 \mathrm{~mm}$ fraction. Criteria used for species identification come from Bé (1977) and Hemleben et al. (1989).

Although core SAN-76 is located above the lysocline, and for this reason we should not expect dissolution problems. However, in order to exclude possible biases caused by preferential dissolution, we analyzed the fragmentation of foraminiferal tests and the relative abundances of planktonic and benthic foraminifera. The fragmentation of planktonic foraminifera is one of the most widely used indices for carbonate dissolution (Howard \& Prell, 1994, Conan et al., 2002). Several studies have demonstrated a progressive (and roughly linear) increase in the fragmentation of foraminifera following an increase in dissolution (Berger, 1967; Thunell \& Honjo, 1981). The relative abundances of planktonic and benthic foraminifera are also used as a dissolution index because planktonic foraminifera are more susceptible to dissolution than benthic specimens due to their porous chamber walls which allow buoyancy in surface waters.

The equations applied were those proposed by Thunell (1976) (eqs. 1 and 2):

Preservation index $=100 * \mathrm{P} / \mathrm{P}+\mathrm{F}$

and

Relative abundance of benthic foraminifera $=100 * \mathrm{~B} /(\mathrm{B}+\mathrm{P})$

where $\mathrm{P}$ is the number of intact planktonic foraminifera, $\mathrm{F}$ is the number of planktonic foraminiferal fragments and $\mathrm{B}$ is the number of benthic foraminifera.

\section{Chronology}

Chronology was based on the correlation of the isotopic record of benthic foraminifera with the SPECMAP chronology of Martinson et al. (1987) and on radiocarbon dating using accelerator mass spectrometer performed on four samples of monospecific planktonic foraminifera, G. ruber $(>250 \mathrm{~mm})$.

Data on the oxygen isotopic composition of benthic foraminifera are based on the analysis of 1-2 Cibicidoides specimens larger than $250 \mathrm{~mm}$ with individual weight ranging from 50 to $150 \mathrm{mg}$. The isotopic analyses were performed at the laboratory facilities of Woods Hole Oceanographic Institution (WHOI), using a Finnigan MAT252 with the automated Kiel device. The standard deviation of the isotope
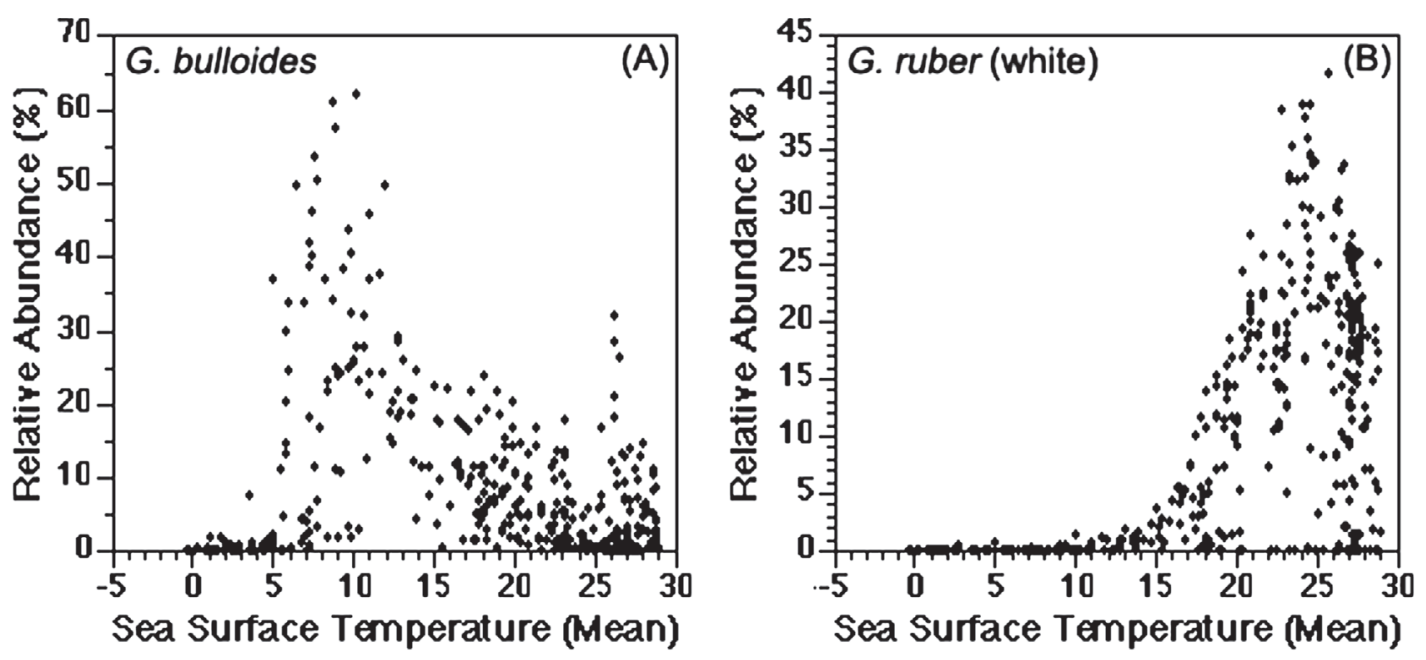

Figure 2. Relationship between annual mean sea surface temperature and the relative abundance of (A) G. bulloides and (B) G. ruber (white), according to Hilbrecht (1996) (based on data from the Atlantic and Indian oceans). 

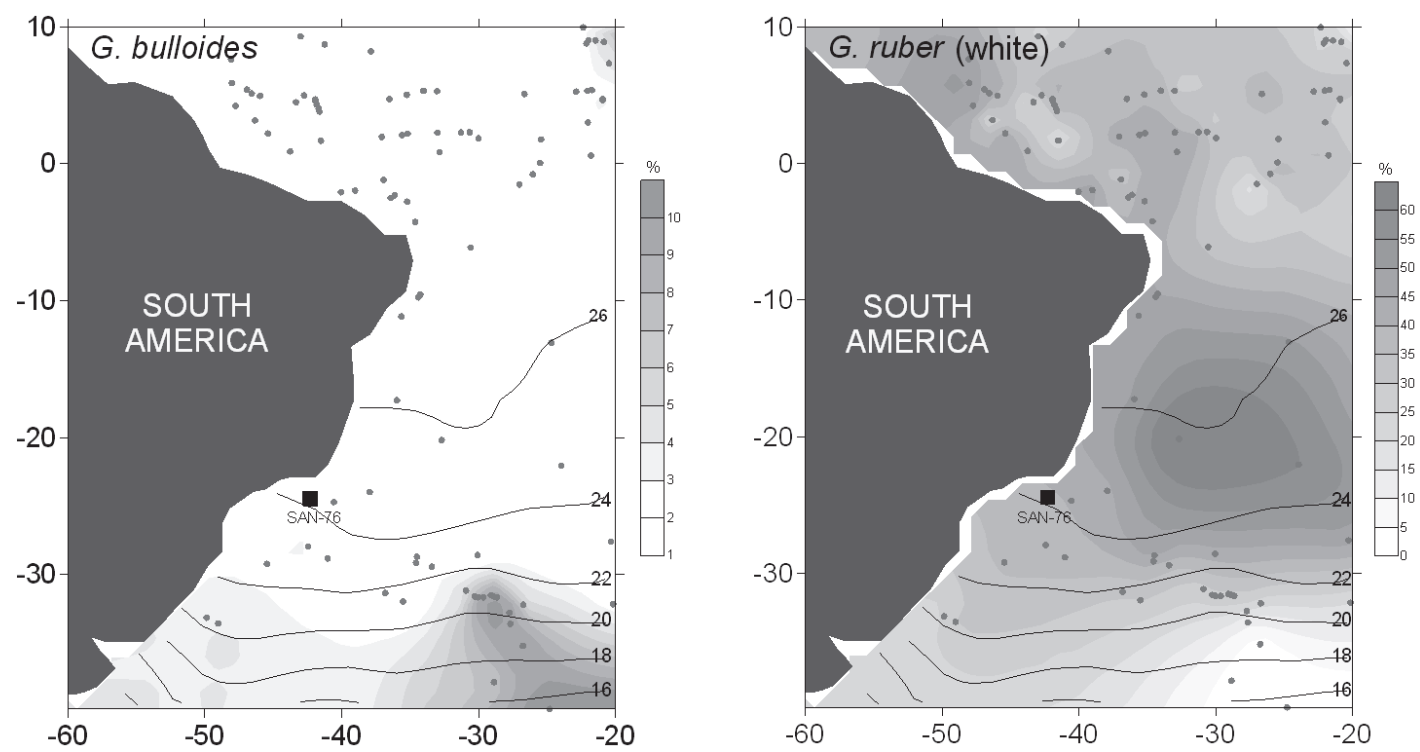

Figure 3. Modern sea surface temperature in the western tropical South Atlantic (Levitus \& Boyer, 1994) vs. the relative abundances (\%) of G. bulloides and G. ruber (white), in surface sediments (fraction >150im) based on data from Pflaumann et al., 1996. Gray dots indicate the location of sampling stations. Contour intervals are $1 \%$ for G. bulloides and $5 \%$ for G. ruber (white).

values of the carbonate standard NBS-19 (National Bureau of Standards, NBS) was $\pm 0.08 \%$. NBS-19 isotope values were used to calibrate to Pee Dee Belemnite $\left(\delta^{18} \mathrm{O}=-2.2\right.$ Vienna Pee Dee Belemnite (VPDB)).

${ }^{14} \mathrm{C}$-AMS dating was performed at the NOSAMS- WHOI laboratory facility, and all the ${ }^{14} \mathrm{C}$ ages were corrected for a reservoir effect of 400 years (Bard, 1988) and converted into calendar years (Table 1). The sedimentation rate decreased from $23 \mathrm{~cm} / \mathrm{kyr}$ during the Last Glacial Maximum (LGM), 11 $\mathrm{cm} / \mathrm{kyr}$ during deglacial times and $4 \mathrm{~cm} / \mathrm{kyr}$ during the Holocene. This difference in the sedimentation rates between LGM and Holocene is mainly attributed to the sea level changes (-130m) (Kowsmann \& Costa, 1979) that exposed the continental shelf, favoring the riverine terrigenous input directly into the continental slope off Brazil (Damuth, 1977).

\section{RESULTS AND DISCUSSION}

\section{Sample preservation}

The distribution of planktonic foraminifera in the sediments reflects not only the living environment in surface waters but also those of preservation on the ocean floor. For this reason, the sedimentary imprint of planktonic

Table 1. Radiocarbon age control points for core SAN-76 obtained by accelerator mass spectrometry (AMS).

\begin{tabular}{ccc}
\hline Depth in core $(\mathrm{cm})$ & ${ }^{14} \mathrm{C}$ age (krys) & Calendar age (years) \\
\hline 13 & 3010 & 2756 \\
148 & 13450 & 15516 \\
320 & 19300 & 22374 \\
416 & 29400 & 33583
\end{tabular}

assemblages is not always straightforward. The most important factor causing differences between the biocoenosis (assemblages of living organisms) and the thanatocoenosis (assemblages of dead organisms) is the selective dissolution of the more susceptible species. In the case of $G$. bulloides and $G$. ruber both species are dissolution succeptible (e.g. Berger, 1970; Boltovskoy \& Totah, 1992). Some authors have stated that both species have similar susceptibilities to dissolution in which case, the use of the ratio G. bulloides to $G$.

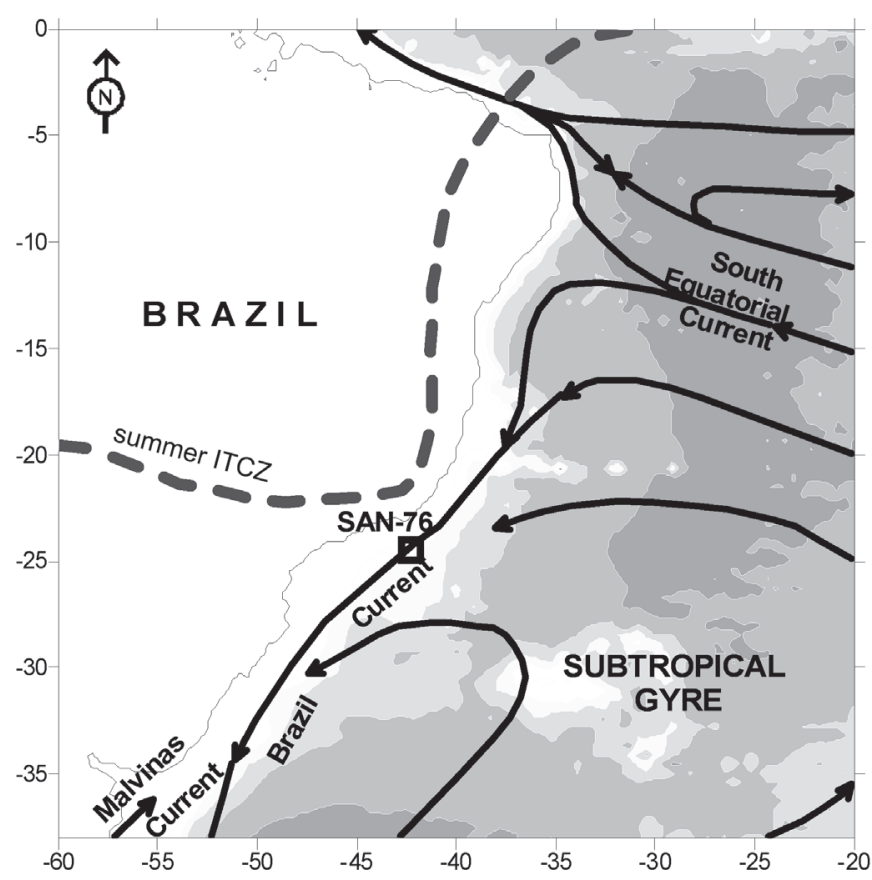

Figure 4. Large-scale surface circulation according to Peterson and Stramma (1991). 
ruber would not be affected. However, Malmgren (1983) and Sautter \& Thunell (1991) claim that G. bulloides is slightly more resistant.

Samples taken from SAN-76 for the last 30kyr showed no signs of dissolution. The good preservation was confirmed by the fragmentation index and the relative abundances of planktonic and benthic foraminifera (Figure 5). Both records suggest better preservation conditions in the Holocene compared to glacial times. However, the lowest preservation values based on the fragmentation of foraminiferal tests do not correlate with the highest relative abundances of benthic foraminifera. This suggests that the observed fragmentation is not related to dissolution, and that the record of the relative abundance of benthics reflects almost exclusively past sealevel changes.

Although both indices are considered good indicators of dissolution, they can also reflect different processes. For instance, fragmentation can also be related to the handling of samples in the laboratory, and the relative abundance of benthic foraminifera can also reflect changes in paleodepths (e.g. ,van der Zwaan et al., 1990) and productivity (e.g., Berger \& Diester-Haas, 1988). In any case, good preservation is confirmed by the high carbonate preservation indices and the low relative abundances of benthic foraminifera.

\section{G bulloides/G ruber proxy}

Globigerinoides ruber (white) clearly dominated the fossil assemblage at core SAN-76 throughout the last 30kyr, with relative abundances ranging from 29 to $51 \%$ (Figure 6). Globigerina bulloides was also a dominant species although during the period under study, it eventually experienced extremely low abundances reaching values close to zero (0.6 and $0.8 \%$ at 14.2 and 15.8 kyr BP, respectively). The maximum relative abundances of $G$. bulloides occurred approximately 21.4 and $26.5 \mathrm{kyr}$ BP. Together, G. ruber and $G$. bulloides account for $38 \%$ to $61 \%$ of the total assemblage in all samples.

The records of G. ruber and G. bulloides (Figure 6) clearly show a negative correlation from $25 \mathrm{kyr}$ to the present with high abundances of $G$. ruber associated with low abundances of $G$. bulloides and vice-versa. Between 30 and $25 \mathrm{kyr}$ BP, this relationship is less clear. Although we must bear in mind the limitations of dealing with relative abundances (fixedsum problem), the inverse relationship between G. ruber and $G$. bulloides further reinforces the idea that the relative abundances of the two species can be used to trace past environmental changes. Yet, what are these environmental changes? Do they represent temperature and/or productivity changes?

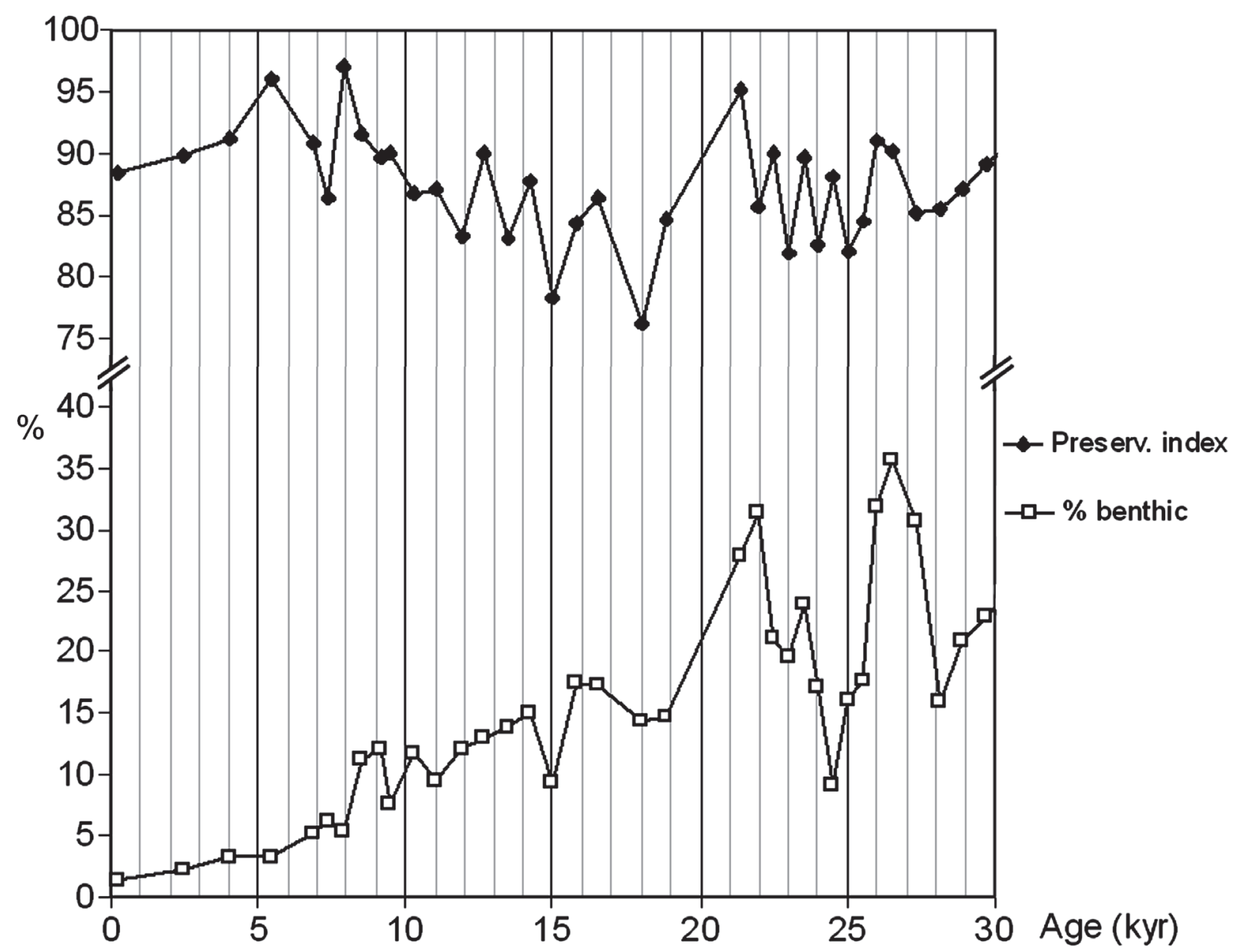

Figure 5. Preservation index and relative abundance of benthic foraminifera for core SAN-76. 


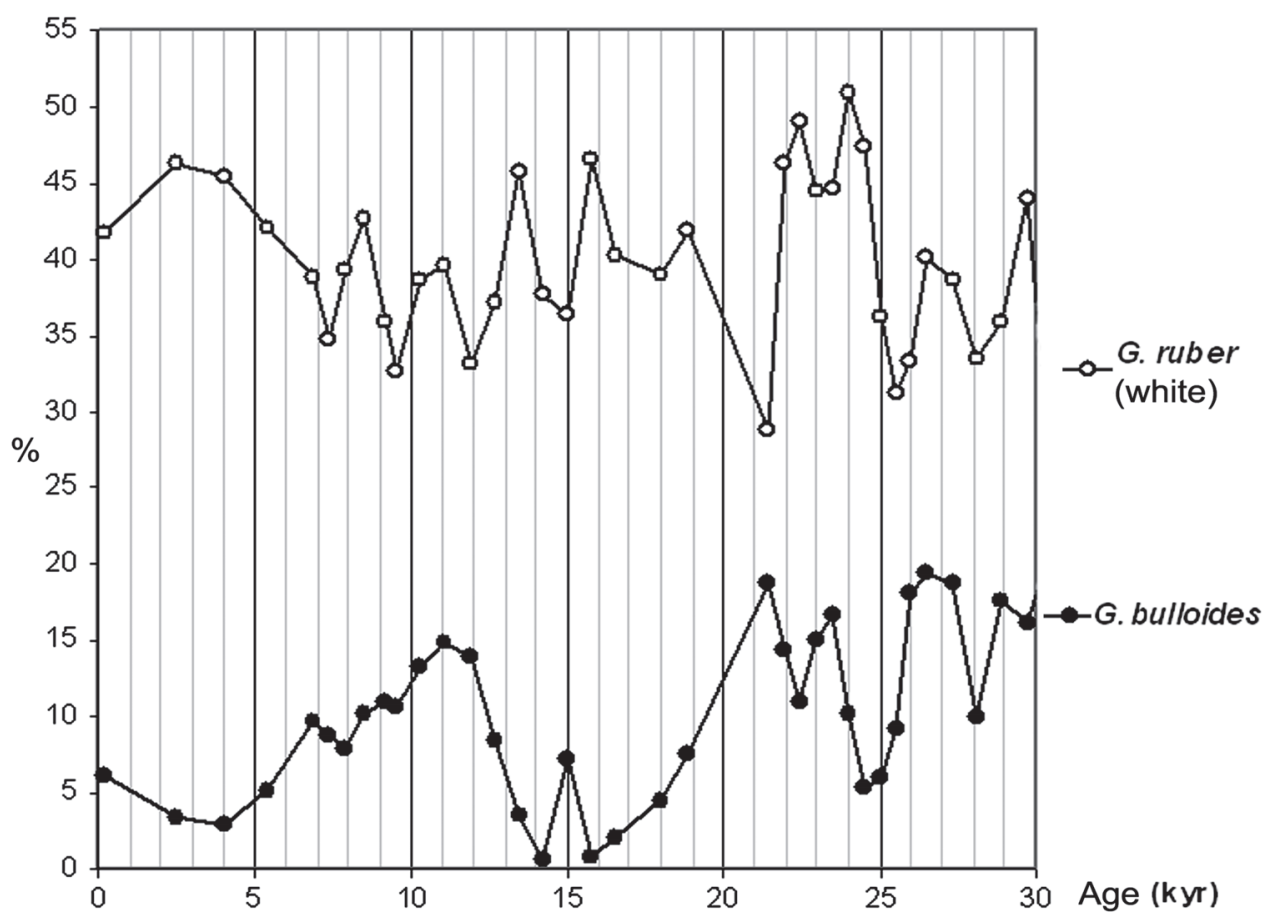

Figure 6. Relative abundances (\%) of G. bulloides and G. ruber (white) during the last $30 \mathrm{kyr}$ at SAN-76.

Figure 7 presents the ratio of G. bulloides to G. ruber (white) for the last $30 \mathrm{kyr}$. The ratio clearly follows the trend of the relative abundance of $G$. bulloides. Although the ratio does not follow a clear glacial/interglacial trend, in general terms, glacial values seem to be higher than Holocene values. Maximum G. bulloides/G. ruber values occurred around $21 \mathrm{kyr}$ $\mathrm{BP}$ and minimum values occurred during the early deglacial around 14 and 16kyr BP. Low values also occurred during the mid-to-late Holocene and during glacial times around $24 \mathrm{kyr} \mathrm{BP}$.

On the one hand, high values of the G. bulloides/G. ruber ratio could be related to cooling events possibly resulting from a northward shift in the climatic belts, and thus, in the biogeographic zones. On the other hand, high values of the G. bulloides to G. ruber ratio could also reflect periods of high productivity. Given the multivariate character of planktonic foraminifera adaptations (Hilbrecht, 1996) we must recognize that the relative abundance changes are indeed consequence of much more than one or two environmental parameters. Even if the relative abundances can be mostly related to water temperature and productivity, we cannot forget that multiple environmental factors also influence species distribution and abundance. In the Table 2 is presented some of the environmental and ecological factors affecting the distribution and relative abundances of $G$. ruber and G. bulloides. The table clearly shows the opposite preferences and adaptations of both species, which makes them useful tracers of past environmental changes.

Based on a study performed in the California margin, Ortiz et al. (1995) suggested that changes in the abundance of symbiotic (e.g., G. ruber) and asymbiotic (e.g., G. bulloides) planktonic foraminifera can be explained by different responses to changes in food availability and light. While food decreases offshore, the light needed for symbiont photosynthesis increases offshore as water turbidity lessens. This way, symbiont-bearing species such as G. ruber dominate the offshore fauna, and the asymbiotic species $G$. bulloides, which is strongly dependent on food availability, dominates the coastal fauna (Ortiz et al., 1995; Abrantes et al., 2002; Meggers et al., 2002).

The observations made by Ortiz et al. (1995) are consistent and probably applicable to our region. However, we cannot forget that interoceanic and even interhemispheric extrapolation of regional ecological data can bias paleoceanographic interpretations (Boltovskoy et al., 1996). This is especially important when dealing with G. ruber and $G$. bulloides, since recent studies have shown that in fact $G$. ruber comprises four different genotypes and G. bulloides six different genotypes (Darling et al., 2000; Kucera \& Darling, 2002), each one with its own ecological adaptations. Nevertheless, all studies dealing with G. bulloides agree that while it can be distributed over a wide temperature range (wider than G. ruber, see Figure 2) its distribution is strongly dependent on productivity.

Since G. bulloides has a clear preference for productive environments where its abundance may be primarily controlled by variations in primary production related to a phytoplankton bloom succession (Hemleben et al., 1989; Sautter \& Thunell, 1991), we can infer that high values of the G. bulloides/G. ruber ratio represent periods of high productivity. In order to verify this hypothesis, we compared the relative abundances of benthic foraminifera (relative to all foraminifera) and G. bulloides (Figure 8). Both records show a clear positive correlation, except during the period between 12 and $18 \mathrm{kyr}$ BP where they display an inverse trend. Based on this relationship, we propose that most of the changes in the G. bulloides/G. ruber ratio represent indeed 


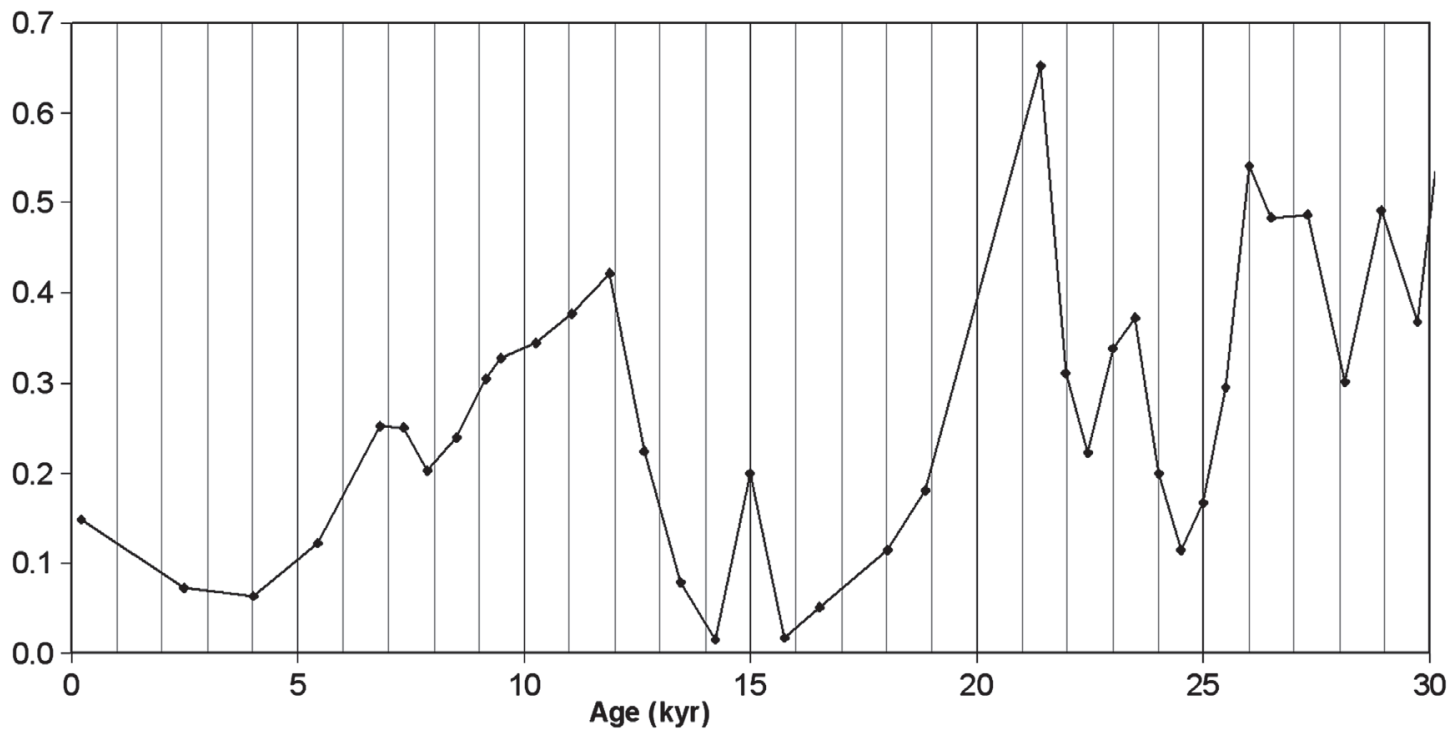

Figure 7. Ratio G. bulloides/G. ruber (white) during the last $30 \mathrm{kyr}$ at SAN-76.

productivity changes. The good correlation between benthic foraminifera and $G$. bulloides also explains the lack of correlation between the preservation index based on fragmentation and the relative abundance of benthic foraminifera (Figure 5), since the latter seems to reflect productivity changes instead of dissolution.

Although we agree that changes in the G. bulloides $/ G$. ruber ratio mainly reflect productivity changes, we also know that these changes are not independent oftemperature changes since, in this area, temperature and productivity are likely to covary. Today, core SAN-76 is located in an oligotrophic area, and thus, the main source of nutrients are the thermocline waters. These nutrient-rich waters originate

Table 2. Relationship of G. bulloides and G. ruber with some important environmental and biological variables. Data from Bé et al. (1977,1985), Hemleben et al. (1989), Sautter \& Thunell (1991), Ortiz et al. (1995), Hilbrecht (1996), Watkins et al. (1998), andKemle-von Mücke \& Hemleben (1999).

\begin{tabular}{|c|c|c|c|}
\hline & & G.bulloides & G.ruber \\
\hline \multirow[b]{2}{*}{$\frac{0}{\frac{0}{0}}$} & Symbionts & Symbiont barren & Symbiotic bearing \\
\hline & $\begin{array}{l}\text { Trophic } \\
\text { Activity }\end{array}$ & $\begin{array}{l}\text { Omnivorous but mostly } \\
\text { herbivorous. }\end{array}$ & $\begin{array}{l}\text { Omnivorous with a } \\
\text { preference for a } \\
\text { carnivorous diet. }\end{array}$ \\
\hline \multirow{3}{*}{ 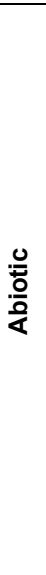 } & $\begin{array}{c}\text { Water } \\
\text { temperature }\end{array}$ & $\begin{array}{l}\text { Present under a wide } \\
\text { range of thermal } \\
\text { environments. Generally } \\
\text { more abundant in cool } \\
\text { subtropical/ transitional } \\
\text { waters. }\end{array}$ & $\begin{array}{l}\text { Distribution is clearly } \\
\text { influenced by water } \\
\text { temperature. Prefers } \\
\text { warmer waters. }\end{array}$ \\
\hline & Productivity & $\begin{array}{l}\text { Largest abundances occur } \\
\text { in eutrophic waters with } \\
\text { high phytoplankton } \\
\text { productivity. }\end{array}$ & $\begin{array}{l}\text { Adapted to oligotrophic } \\
\text { environments. }\end{array}$ \\
\hline & $\begin{array}{l}\text { Light (see } \\
\text { symbionts) }\end{array}$ & $\begin{array}{c}\text { Being an asymbiotic } \\
\text { species, it is not } \\
\text { significantly influenced by } \\
\text { light. Thus, this species } \\
\text { can dwell in more turbid } \\
\text { waters. }\end{array}$ & $\begin{array}{l}\text { Light is needed for } \\
\text { symbiont photosynthesis. } \\
\text { Abundance increases } \\
\text { offshore as water turbidity } \\
\text { lessens. }\end{array}$ \\
\hline
\end{tabular}

in the Subtropical Convergence Zone (STCZ), and therefore, they are also colder.

\section{Circulation changes during the past $30 \mathrm{kyr}$}

The G. bulloides/G. ruber ratio suggests that the region of core SAN-76 experienced significant oceanographic changes during the last 30kyr (Figure 7). Based on the previous discussion, we suggest that the observed changes are mainly related with paleoproductivity but they reflect temperature changes, as well. Periods of low G. bulloides $/ G$. ruber values would characterize the influence of warm, oligotrophic waters and, conversely, periods of high $G$. bulloides/G. ruber values would represent periods influenced by colder and nutrient-rich waters.

Both temperature and nutrient availability are strongly dependent on the regional wind field. As detailed in the present oceanographic setting, different types of water are carried by the western boundary current at different depths, and therefore, it is reasonable to expect that a north-south displacement of the SEC bifurcation latitude would have strong impacts on the effectivity of the upwelling regime in the Cabo Frio region. Since the SEC bifurcation is dependent on the wind regime over the basin, if the atmospheric anticyclone over the Atlantic were located more to the north, we should expect a northward shift of the bifurcation. This would likely result in more SACW and less TW in the Cabo Frio region (i.e. better conditions for $G$. bulloides). On the contrary, a southward shift of the wind anticyclone would imply a southward displaced birfurcation, and, consequently, more TW and less SACW available in the study area (i.e., conditions less favorable to G. bulloides).

Similar to the present seasonal cycle, past changes in the wind field and the migration of the ITCZ must have caused significant changes in the surface currents and hence, in the distribution of heat and nutrients. In orbital time-scales, these changes must have been much more significant than the present seasonal cycle. Indeed, several paleoceanographic 


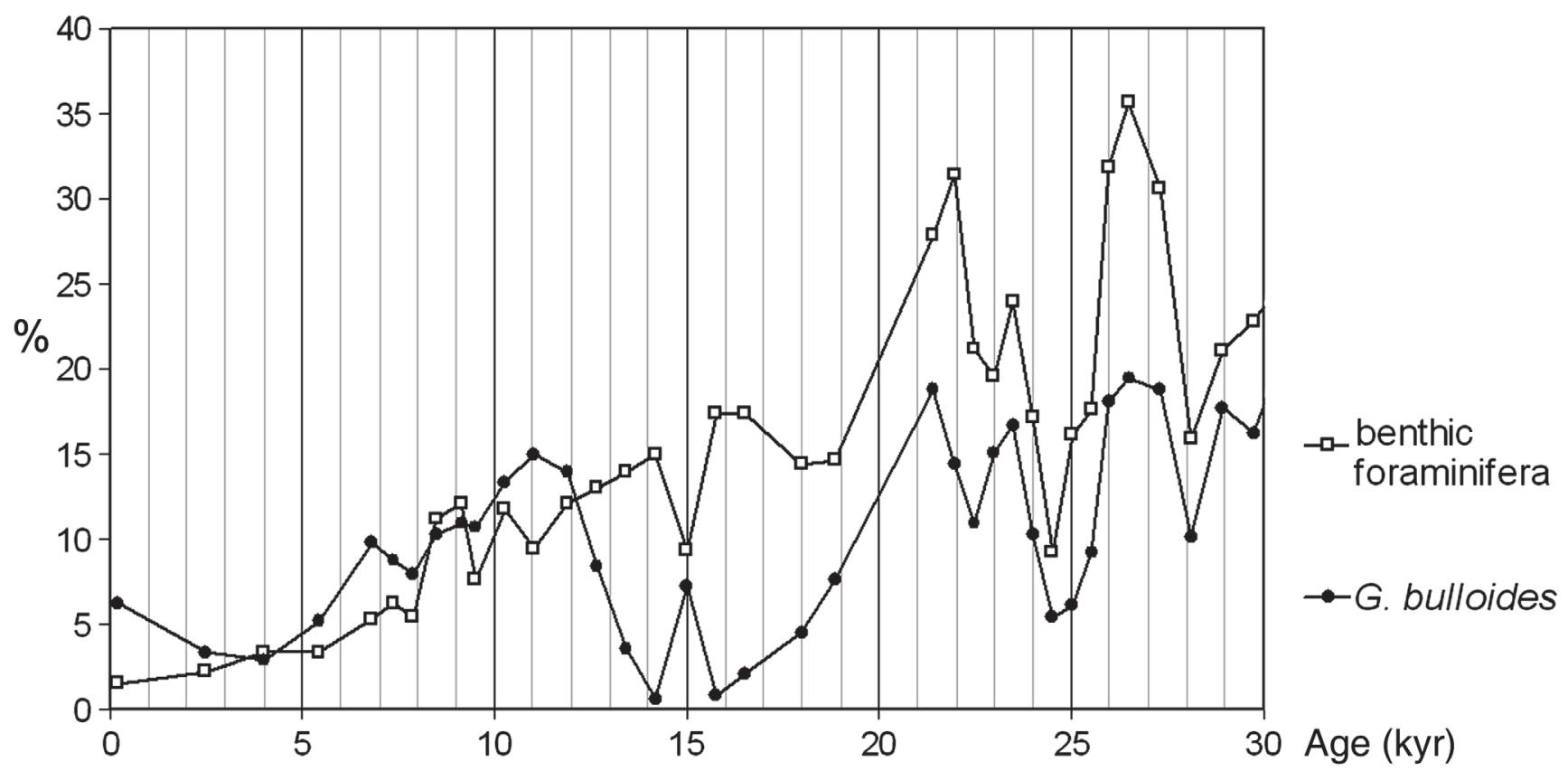

Figure 8. Comparison of the relative abundances of G. bulloides and benthic foraminifera relative to all planktonic foraminifera.

studies point to a strong connection between the northward shift of the zero wind-stress curl in the South Atlantic and the abundance variability of some foraminifera species. For instance, Berger \& Wefer (1996) showed that the planktonic foraminifer Globorotalia menardii disappeared from the South Atlantic (but not from the Indian Ocean) during the last glacial period. They speculate that this was most likely because of a decrease of the upper ocean's temperature due to a northward shift of the line of zero wind-stress curl. The same species later reappeared following a return of this line to southernmost positions, which would have reopened the Agulhas connection allowing for a reseeding from the Indian to the Atlantic Ocean. Other paleoceanographic data (Howard \& Prell, 1992) indicate large shifts of the major southern ocean fronts on glacial-interglacial timescales. According to these data, during the last glacial period the position of the STCZ was several degrees to the north of its present-day position. In this case, it would be reasonable to expect an increase in the G. bulloides/G. ruber ratio in that period.

Assuming that the ages of our samples are reasonably well constrained, we proceed to analyze the changes observed in our record (Figure 7). As previously mentioned, the changes did not follow a clear glacial/interglacial trend, although in general terms, glacial times seem to have been more productive than the Holocene, where our proxy indicates a gradual decrease in productivity. The highest $G$. bulloides/G. ruber value occurred at the LGM, around 21 kyr BP. An increased productivity during the LGM is consistent with the stronger trade winds (Kim \& Schneider, 2003), shallower thermocline (Ravelo \& Andreasen, 1999) and reduced geographical extension of the tropical assemblage (Niebler et al., 2003) suggested for this time period. Stronger SE trade winds during the LGM may have also strenghthened the SEC and the NBC in detriment of the $\mathrm{BC}$.

The lowest values of G. bulloides/G. ruber occurred around 17-15.5 and $14 \mathrm{kyr} \mathrm{BP}$. The first low is coincident with Heinrich event 1 ( 16.9-15.4 kyr BP), when thermohaline circulation was particularly weak and the western South Atlantic acted as a heat reservoir. Evidence for this time period points to weak SE trade winds (Kim \& Schneider, 2003) and to a strengthening of the BC (Arz et al., 1999) which are both consistent with our estimate of a severe decrease in productivity. Heinrich event 1 was followed by the BollingAllerod interglacial ( 15.4-13 kyr BP) when, according to Kim $\&$ Schneider (2003), SE trade winds were weak. This agrees with our estimates of reduced productivity for this time period, related to a deepened thermocline, a reduced NBC and a strengthened BC.

Another peak in productivity occurred during the Younger Dryas ( 13-11.5 kyr BP) when thermohaline circulation was weak and the SE trade winds were similar to those during the LGM but NE trade winds were stronger (Kim \& Schneider, 2003). The seasonal contrast in the southern hemisphere was reduced during the Younger Dryas, since the earth was closer to the sun in June and farther in December (Berger \& Loutre, 1991). As a result, the ITCZ was located farther north, probably intensifying the penenetration of polar advections (Martin et al., 1997), and favoring the influence of colder, nutrient-rich waters.

Finally, our record suggests a gradual decrease in productivity from $11 \mathrm{kyr} \mathrm{BP}$ through the Holocene which can be explained by a progressively stronger $\mathrm{BC}$ resulting from a southward displacement of the ITCZ. The general southward migration of the ITCZ would be a consequence of insolation changes related to the precessional cycle (Haug et al., 2001). 


\section{CONCLUSIONS}

The multivariate character of the ecological adaptations of planktonic foraminifera prevent us from making precise reconstructions of past climates based exclusively in the relative abundances of two species. However, we have shown that the ratio of $G$. bulloides to $G$. ruber can be used to trace general oceanographic changes, mostly related to productivity changes. Although the relative abundance of $G$. bulloides alone could be used as a proxy for productivity, the use of G. bulloides together with G. ruber, each species representative of a biogeographic province and thereby excluding ecological preferences, provides more robust estimates. Whenever both species show a negative covariance we can assume that the environmental changes they reflect are related to temperature and productivity. However, in order to provide more detailed reconstructions, the G. bulloides $/ G$. ruber ratio should be used together with other proxies.

Samples taken from core SAN-76, from intermediate depths in the Brazilian Continental Margin were well preserved and showed no signs of dissolution. The $G$. bulloides/G. ruber record suggests that important productivity changes occurred during the past $30 \mathrm{kyr}$. We speculate that these are the result of changes in the wind field related to the meridional shifts of the atmospheric anticyclone over the Atlantic. A northward shift of the anticyclone would result in a northward SEC bifurcation, and hence in an increased availability of the nutrient-rich SACW and less warm oligotrophic TW at the study area. This seems to have occurred during the LGM and Younger Dryas. Conversely, a southward shift of the anticyclone would bring more TW to the southeastern Brazilian Continental Margin, leading to a decrease in productivity as took place between 17 and $14 \mathrm{kyr}$ BP and subsequently during the course of the Holocene. Our results are in agreement with other paleoceanographic and paleoclimatic studies providing estimates of changes in trade wind strength and the extent of climatic belts.

\section{ACKNOWLEDGMENTS}

This study was financially supported by Fundação de Amparo à Pesquisa do Estado de São Paulo (proc. 04/028198 ) and the Conselho Nacional de Desenvolvimento Científico e Tecnológico (proc. 141577/2005-3). We thank Petrobras for providing the samples. This is Laboratório de Paleoceanografia do Atlântico Sul (LaPAS) contribution number 09 .

\section{REFERENCES}

Abrantes, F.; Meggers, H.; Nave, S.; Bollman, J.; Palma, S.; Sprengel, C.; Henderiks, J.; Spies, A.; Salgueiro, E.; Moita, T. \& Neuer, S. 2002. Fluxes of micro-organisms along a productivity gradient in the Canary Islands region $\left(29^{\circ} \mathrm{N}\right)$ : Implications for paleoreconstructions. Deep-Sea Research II, 49:3599-3629.

Arnold, A.J. \& Parker, W.C. 1999. Biogeography of Planktonic
Foraminifera. In: B.K. Sen Gupta (ed.) Modern Foraminifera, Kluwer Academic Publishers, p. 103- 122.

Arz, H.W.; Pätzold, J. \& Wefer, G. 1999. The deglacial history of the western tropical Atlantic as inferred from high resolution stable isotope records off northeastern Brazil. Earth \& Planetary Science Letters, 167:105-117.

Bard, E. 1988. Correction of accelerator mass spectrometry ${ }^{14} \mathrm{C}$ ages measured in planktonic foraminifera: Paleoceanographic implications. Paleoceanography, 3:635-645.

Bé, A.W.H. 1977. An ecological, zoogeographic and taxonomic review of recent planktonic foraminifera. In: A.T.S. Ramsay (ed.) Oceanic Micropaleontology, Academic Press, p. 1-100.

Bé, A.W.H.; Bishop, J.K.B.; Sverdlove. M.S. \& Gardner, W.D. 1985. Standing stock, vertical distribution and flux of planktonic foraminifera in the Panama Basin. Marine Micropaleontology, 9:307-333.

Bé, A.W.H.; Hemleben, C.; Anderson, O.R.; Spindler, M.; Hacunda, J. \& Tuntivate-Choy, S. 1977. Laboratory and field observations of living planktonic foraminifera. Micropaleontology, 23(2):155-179.

Bé, A.W.H \& Hutson, W.H. 1977. Ecology of Planktonic Foraminifera and Biogeographic Patterns of Life and Fossil Assemblages in the Indian Ocean. Micropaleontology, 23(4):369-414.

Berger, W. H. 1967. Foraminiferal ooze: solution at depths. Science, 156:383-385.

Berger, W.H. 1970. Planktonic foraminifera: Selective solution and the lysocline. Marine Geology, 8(2):111-138.

Berger, W.H. \& Diester-Haas, L. 1988. Paleoproductivity: The benthic/planktonic ratio in foraminifera as a productivity index. Marine Geology, 81(1-4):15-25.

Berger, A. \& Loutre, M.F. 1991. Insolation values for the climate of the last 10 million years. Quaternary Science Reviews, 10:297317.

Berger, W.H. \& Wefer, G. 1996. Expeditions into the past: Paleoceanographic studies in the South Atlantic. In: G. Wefer; W.H. Berger; G. Siedler \& D.J. Webb (eds.), The South Atlantic: Present and Past Circulation. Springer-Verlag, p. 363-410.

Boltovskoy, E. \& Wright, R. 1976. Recent Foraminifera. W. Junk, The Hague, 515 p.

Boltovskoy, E. \& Totah, V. 1992. Preservation index and preservation potential of some foraminiferal species. Journal of Foraminiferal Research, 22(3):267-273.

Boltovskoy, E.; Boltovskoy, D.; Correa, N. \& Brandini, F. 1996. Planktic foraminifera from the southwestern Atlantic (30-60 $\mathrm{S})$ : species-specific patterns in the upper $50 \mathrm{~m}$. Marine Micropaleontology, 28:53-72.

Campos, E.J.D.; Gonçalves, J.E. \& Ikeda, Y. 1995. Water mass characteristics and geostrophic circulation in the South Brazil Bight: Summer of 1991. Journal of Geophysical Research, 100(C9): 18537-18550.

Campos, E.J.D.; Velhote, D. \& da Silveira, I.C.A. 2000. Shelf break upwelling driven by the Brazil Current cyclonic meanders. Geophysical Research Letters, 27(6):751-754.

Conan, S.M.H.; Ivanova, E.M. \& Brummer, G.J.A. 2002. Quantifying carbonate dissolution and calibration of foraminiferal dissolution indices in the Somali Basin. Marine Geology, 182:325-349.

Damuth, J.E. 1977. Late Quaternary sedimentation in the western equatorial Atlantic. Geological Society of America Bulletin, 88:695-710.

Darling, K.F.; Wade, C.M.; Stewart, I.A.; Kroon, D.; Dingle, R. \& 
Leigh Brown, A.J. 2000. Molecular evidence for genetic mixing of Arctic and Antarctic subpolar populations of planktonic foraminifers. Nature, 405:43-47.

Goni, G.J. \& Wainer, I. 2001. Investigation of the Brazil Current front variability from altimeter data. Journal of Geophysical Research, 106(C12):31117-31128.

Haug, G.H.; Hughen, K.A.; Sigman, D.M.; Peterson, L.C. \& Röhl, U. 2001. Southward migration of the Intertropical Convergence Zone through the Holocene. Science, 293:1304-1308.

Hemleben, C.; Spindler, M. \& Anderson, O.R. 1989. Modern Planktonic Foraminifera. Springer-Verlag, New York, 363 p.

Hilbrecht, H. 1996. Extant planktic foraminifera and the physical environment in the Atlantic and Indian Oceans. Mitteilungen aus dem Geologischen Institut der Eidgen. Technischen Hochschule und der Universität Zürich, Neue Folge, 300: 1-93.

Howard, W.R. \& Prell, W.L. 1992. Late Quaternary surface circulation of the southern Indian Ocean and its relationship to orbital variation. Paleoceanography, 7:79-117.

Howard, W.R. \& Prell, W.L. 1994. Late Quaternary $\mathrm{CaCO}_{3}$ production and preservation in the Southern Ocean: Implications for oceanic and atmospheric carbon cycling. Paleoceanography, 9:453-482.

Johns, W.E.; Lee, T.N.; Beardsley, R.C.; Candela, J.; Limeburner, R. \& Castro, B. 1998. Annual cycle and variability of the North Brazil current. Journal of Physical Oceanography, 28(1):103128.

Kemle-von Mücke, S. \& Hemleben, C. 1999. Foraminifera. In: D. Boltovskoy (ed.) South Atlantic Zooplankton, Backhuys Publishers, p. 43-73.

Kim, J.H. \& Schneider, R.R. 2003. Low-latitude control of interhemispheric sea-surface temperature contrast in the tropical Atlantic over the past 21 kyears: the possible role of SE trade winds. Climate Dynamics, 21:337-347.

Kowsmann, R.O. \& Costa, M.P.A. 1979. Sedimentação Quaternária da Margem Continental Brasileira e das Áreas Oceânicas Adjacentes. CENPES/PETROBRÁS, Rio de Janeiro, 55 p. (Série Projeto REMAC, 8).

Kucera, M. \& Darling, K.F. 2002. Cryptic species of planktonic foraminifera: their effect on paleoceanographic reconstructions. Philosophical Transactions of the Royal Society of London, Series A, 360:695-718.

Levitus, S. \& Boyer, T. 1994. World Ocean Atlas 1994 Volume 4: Temperature. Washington, D.C., U.S. Department of Commerce, NOAA Atlas (NESDIS 4).

Malmgren, B.A. 1983. Ranking of dissolution susceptibility of planktonic foraminifera at high latitudes of the South Atlantic Ocean. Marine Micropaleontology, 8:183-191.

Martin, L.; Bertaux, J.; Corrège, T.; Ledru, M.P.; Mourguiart, P.; Sifeddine, A.; Soubiès, F.; Wirrmann, D.; Suguio, K. \& Turcq, B. 1997. Astronomical forcing of contrasting rainfall changes in tropical South America between 12.400 e $8.800 \mathrm{cal} \mathrm{yr} \mathrm{B.} \mathrm{P.}$ Quaternary Research, 47:117-122.

Martinson, D.G.; Pisias, N.G.; Hays, J.D.; Imbrie, J.T.C.; Moore J. \& Shackleton, N.J. 1987. Age Dating and the Orbital Theory of the Ice Ages: Development of a High-Resolution 0 to 300,000Year Chronostratigraphy. Quaternary Research, 27:1-29.
Matano, R.P.; Schlax, M.G. \& Chelton, D.B. 1993. Seasonal variability in the southwestern Atlantic. Journal of Geophysical Research, 98(C10):18027-18036.

Meggers, H.; Freudenthal, T.; Nave, S.; Targarona, J.; Abrantes, F. \& Helmke, P. 2002. Assessment of geochemical and micropaleontological sedimentary parameters as proxies of surface water properties in the Canary Islands region. DeepSea Research II, 49:3631-3654.

Morey, A.E.; Mix, A.C. \& Pisias, N.G. 2005. Planktonic foraminiferal assemblages preserved in surface sediments correspond to multiple environmental variables. Quaternary Science Reviews, 24:925-950.

Niebler, H.S.; Arz, H.W.; Donner, B.; Mulitza, S.; Pätzold, J. \& Wefer, G. 2003. Sea surface temperatures in the equatorial and South Atlantic Ocean during the Last Glacial Maximum (23-19 ka). Paleoceanography, 18(3):1069.

Ortiz, J.D.; Mix, A.C. \& Collier, R.W. 1995. Environmental control of living symbiotic and asymbiotic foraminifera of the California Current. Paleoceanography, 10(6):987-1009.

Peterson, R.G. \& Stramma, L. 1991. Upper-level circulation in the South Atlantic Ocean. Progress in Oceanography, 26:1-73.

Pflaumann, U.; Duprat, J.; Pujol, C. \& Labeyrie, L. 1996. SIMMAX: A modern analog technique to deduce Atlantic sea surface temperatures from planktonic foraminifera in deep-sea sediments. Paleoceanography, 11(1):15-36.

Ravelo, A. C. \& Andreasen, D.H. 1999. Using planktonic foraminifera as monitors of the tropical surface ocean. In: F. Abrantes \& A. Mix (eds.) Reconstructing Ocean History - A window into the future. Plenum Press, p. 217-244.

Ravelo, A.C.; Fairbanks, R.G. \& Philander, S.G.H. 1990. Reconstructing tropical Atlantic hydrography using planktonic foraminifera and an ocean model. Paleoceanography, 5(3):409431.

Sautter, L.R. \& Thunell, R.C. 1991. Planktonic foraminiferal response to upwelling and seasonal hydrographic conditions: sediment trap results from San Pedro Basin, Southern California Bight. Journal of Foraminiferal Research, 21(4):347-363.

Stramma, L. 1989. The Brazil Current transport south of $23^{\circ} \mathrm{S}$. Deep-Sea Research, 36:639-646.

Thunell, R.C. 1976. Optimum indices of calcium carbonate dissolution in deep-sea sediments. Geology, 4:525-528.

Thunell, R.C. \& Honjo, S. 1981. Calcite dissolution and the modification of planktonic foraminiferal assemblages. Marine Micropaleontology, 6:169-182.

Tolderlund, D. \& Bé, A.W.H. 1971. Seasonal distribution of planktonic foraminifera in the Western North Atlantic. Micropaleontology, 17(3):297-329.

Van der Zwaan, G.J.; Jorissen, F.J. \& Stigter, H.C. 1990. The depth dependency of planktonic/benthic foraminiferal ratios: Constraints and applications. Marine Geology, 95(1):1-16.

Watkins, J.M.; Mix, A.C. \& Wilson, J. 1998. Living planktonic foraminifera in the central tropical Pacific Ocean: articulating the equatorial 'cold tongue' during La Niña, 1992. Marine Micropaleontology, 33:157-174.

Received in February, 2008; accepted in August, 2008. 